We thank J. Ostrom for data on Archaeopteryx and A. W. Crompton for access to fabrosaurid and heterodontosaurid material. Supported in part by the National Science Foundation.

Department of Vertebrate Paleontology, ROBERT T. BAKKER

Museum of Comparative Zoology,

Harvard University,

Cambridge, Massachussetts 02138

Department of Biology,

University of Bridgeport,

Bridgeport, Connecticut 06602

Received June 25; revised October 8, 1973.

1 Ostrom, J. H., Q. Rev. Biol. (in the press, 1974).

2 Bakker, R. T., in Perspectives of Biophysical Ecology (edit. by Gates, D., and Schmerl, R. B.) (New York, in the press).

3 Enlow, D. H., and Brown, S. O., Tex. J. Sci., 2, 186 (1957).

4 Currey, J. D., Palaeontology, 5, 238 (1962).

5 Ricqles, A., Annls. Paleont., 54, 9 (1968).

6 Bakker, R. T., Evolution, 25, 363 (1971).

7 Bakker, R. T., Nature, 238, 81 (1972).

8 Ostrom, J. O., Nature, 242, 136 (1973).

9 Bonaparte, J. F., Proc. Pap. 2nd Gond. Symp. S. Afr., 665 (Council for Scientific and Industrial Research, Pretoria, 1972).

10 Bonaparte, J. F., Op. lilloana, 22, 183 (1971).

11 Casamiquela, R. M., Ameghiniana, 4, 47 (1967).

12 Reig, O. A., Ameghiniana, 3, 3 (1963).

13 Romer, A. S., Breviora, 389, 1 (1972).

14 Thulborn, R. A., Nature, 234, 75 (1971).

15 Cruickshank, A. R., in Studies in Vertebrate Evolution (edit. by Joysey, K. A., and Kemp, T. S.) (Oliver and Boyd, Edinburgh,

16 Young, C. C., Mem. Inst. vertebr. Paleont. Peking, 10, 15 (1973).

17 Walker, A. D., Phil. Trans. R. Soc., B, 244, 103 (1961).

18 Walker, A. D., Phil. Trans. R. Soc., B, 248, 53 (1964).

19 Walker, A. D., Phil. Trans. R. Soc., B, 257, 323 (1970).

$20 \mathrm{Kuhn,O}$., in Die Saurier der Deutschen Trias (Verglag Oeben, München, 1971).

21 Romer, A. S., in Vertebrate Paleontology (University of Chicago Press, Chicago, 1967).

22 Charig, A. J., Attridge, J., and Crompton, A. W., Proc. Linn. Soc. Lond., 176, 197 (1965).

23 Romer, A. S., Breviora; 395, 1 (1972).

24 Charig, A. J., in Studies in Vertebrate Evolution (edit. by Joysey, K., and Kemp, T.) (Oliver and Boyd, Edinburgh, 1972).

25 Sawin, H. J., J. Paleont., 21, 201 (1947).

26 Huene, F., von, in Die fossilen Reptilien des Südamerikanischen Gondwanalandes (C. H. Beck'sche Verlagsbuchhandlang, München, 1935-1942).

${ }^{27}$ Soergel, W., in Die Fahrten der Chirotheria (Jena, 1926).

28 Krebs, B., Schweiz. Palaeont. Abh., 81, 1 (1965).

29 Galton, P. M., Arnoldia, 15, 1 (1971).

30 Galton, P. M., Lethaia, 4, 453 (1971).

31 Charig, A. J., and Crompton, A. W., Boonstra Commemorative Vol. (Cape Town, in the press).

32 Hughes, B., S. Afr. J. Sci., 59, 221 (1963).

33 Sill, W., Bull. Mus. Comp. Zool. Harv. (in the press)

34 Bonaparte, J. F., Zoo. J. Linn. Soc., 48, 471 (1969).

33 Huene, F. von, Paläont. Z., 16, 145 (1942).

36 Raath, M. A., Arnoldia, 28, 1 (1969).

37 Cott, H. B., Trans. zool. Soc. Lond., 29, 211 (1961)

38 Colbert, E. H., Amer. Mus. Novitates, 2405, 1 (1970).

39 Galton, P. M., Paläont. Z., 47, 229 (1973).

40 Galton, P. M., Palaiont. Z., 47, 229 (1973). 25,1 (1974)

41 Bakker, R. T., Physiologist, Lond. 15, 3 (1972).

42 Romer, A. S., Breviora, 378, 1 (1971).

43 Romer, A. S., Breviora, 394, 1 (1972)

44 Thulborn, R. A., Palaeontology, 13, 414 (1970).

45 Galton, P. M., J. Paleont., 45, 781 (1971).

46 Ride, W. D., Syst. Ass. Pub., 3, 33 (1959).

47 Galton, P. M., Lethaia, 6, 67 (1973).

48 Galton, P. M., Evolution, 24, 448 (1970).

49 Walker, A. D., Nature, 237, 257 (1972).

30 Ostrom, J. H., K. ned. Akad. v. Wet., B, 75, 289 (1972).

51 Dunson, W. A., Am. J. Physiol., 216, 995 (1965).

32 De Beer, G., in Archaeopteryx lithographica (British Museum (Natural History), London, 1954).

33 Heilmann, G., in The Origin of Birds (D. Appleton and Co., New York, 1927).

54 Ostrom, J. H., Bull. Peabody Mus. nat. Hist., 35 (1970).

ss Ostrom, J. H., Bull. Peabody Mus. nat. Hist., 30 (1969).

\section{Viroids and viral hepatitis in marmosets}

DIENER $^{1}$ and Zuckerman' have recently speculated that hepatitis $A$ and $B$, respectively, may be caused by infective naked nucleic acids or viroids. In response to their hypotheses, we felt it would be of interest to investigate the nature of an agent known to cause hepatitis in marmoset monkeys. We reasoned that if the aetiologic agent of hepatitis found in serum is a free, or naked, nucleic acid in this system, then its infectivity should be destroyed by the action of a specific endonuclease. For example, a free viral DNA would be rendered uninfective after treatment with pancreatic DNase. The virus used in our study was the 'Barker' agent, originally recovered by Deinhardt et al. from acute phase sera of marmosets inoculated with serum from a human case of viral hepatitis ${ }^{3}$. This virus consistently induces hepatitis in such animals, although its pedigree as a human hepatitis agent has been a subject of controversy ${ }^{4}$.

As many animal sera contain RNase activity, but not DNase activity, we assumed the postulated viroid for Barkerinduced marmoset hepatitis, if it existed, would most likely be a naked DNA. To test this assumption, we divided a pool of infective acute-phase marmoset serum into two equal aliquots. One aliquot, was treated with pancreatic DNase (EC 3.1.4.5) at $20 \mu \mathrm{g} \mathrm{ml}-1$ for 1 h at $37^{\circ} \mathrm{C}$; the other aliquot was heated to $37^{\circ} \mathrm{C}$ for $1 \mathrm{~h}$ without any other treatment. Three $S$. nigricollis marmosets were inoculated intravenously (i.v.) with treated serum $(0.25 \mathrm{ml}$ each); three other $S$. nigricollis marmosets were inoculated i.v. with untreated serum. The course of infection in each marmoset was monitored by measuring serum glutamic pyruvic transaminase (SGPT) and serum isocitric dehydrogenase (SICD) activities as indicator enzymes for liver damage.

All six marmosets demonstrated elevated SGPT and SICD activities by. the fourth or fifth week after inoculation, indicating liver damages had been sustained in each animal. Clearly, then, the marmoset hepatitis agent cannot be a DNA viroid as all three animals receiving DNase treated serum showed convincing enzymatic evidence of viral hepatitis. The results of our preliminary study are consistent with the tentative finding by Deinhardt et al." that the Barker hepatitis agent bands in $\mathrm{CsCl}$ at a buoyant density of 1.2. Viruses usually band around $\rho=1.2-1.4$, whereas free viral DNA bands at about $\rho=1.7$.

While the possibility still exists that the marmoset hepatitis agent is another type of viroid, that is, a unique double-stranded RNA (or RNA:DNA hybrid)-protein conjugate which bands in $\mathrm{CsCl}$ at $\rho=1.2$, our experimental evidence at least rules out the presence of a simple DNA viroid in serum containing the marmoset agent.

\section{W. Bradley \\ D. H. Krushak \\ J. E. Maynard}

Phoenix Laboratories, Bureau of Epidemiology, Center for Disease Control. 4402 North Seventh Street, Phoenix, Arizona 85014

Received November 29, 1973.

1 Diener, T. O., Agric. Res. USDA, February (1972).

2 Zuckerman, A. J., Lancet, 1, 1468 (1973).

3 Deinhardt, F. Holmes, A., Capps, R., and Popper, H., J. exp. Med., 125, 673 (1967).

4 Parks, W., and Melnick, J., J. infect. Dis., 120, 539 (1969).

5 Deinhardt, F.. Wolfe, L., Junge, U., and Holmes, A., C.M.A $J ., 106,468$ (1972). 